\title{
Evaluation of a modified method of extraction, purification, and characterization of lipopolysaccharide ( $O$ antigen) from Salmonella Typhimurium
}

\author{
Heba M. Hassan ${ }^{1}$, Mai A. Fadel ${ }^{2}$ (D) and Mohamed A. Soliman ${ }^{1}$ (D)
}

1. Reference Laboratory for Veterinary Quality Control on Poultry Production, Animal Health Research Institute, Agriculture Research Center ARC, Dokki, Giza, Egypt; 2. Pharmacology and Pyrogen Unit, Department of Chemistry, Toxicology and Food Deficiency, Animal Health Research Institute, Agriculture Research Center, Dokki, Giza, Egypt.

Corresponding author: Mohamed A. Soliman, e-mail: mohahm@hotmail.com

Co-authors: HMH: omss2004@yahoo.com, MAF: dr.mai87@yahoo.com

Received: 16-06-2020, Accepted: 23-09-2020, Published online: 05-11-2020

doi: www.doi.org/10.14202/vetworld.2020.2338-2345 How to cite this article: Hassan HM, Fadel MA, Soliman MA (2020) Evaluation of a modified method of extraction, purification, and characterization of lipopolysaccharide (O antigen) from Salmonella Typhimurium, Veterinary World, 13(11): 2338-2345.

\begin{abstract}
Background and Aim: Lipopolysaccharide (LPS) is an integral part of the outer cell membrane complex of Gram-negative bacteria. It plays an important role in the induction and stimulation of the immune system. Various LPS purification protocols have been developed. However, analysis of their efficacy is limited by contamination during downstream applications or the public health hazard of LPS. The aim of this study was to evaluate a modified method for extracting LPS as well as assess the purity of the extracted LPS by high-performance liquid chromatography (HPLC) analysis. Further, we evaluated its immunopotentiating function by measuring the relative RNA expression levels of splenic immune-related genes such as interleukin $1 \beta$ (IL-1 $\beta$ ) and interferon- $\gamma($ IFN- $\gamma$ ), after intramuscular injection of increasing concentrations of the extracted LPS in specific pathogen-free (SPF) chick.
\end{abstract}

Materials and Methods: Isolation, identification, and serotyping of Salmonella Typhimurium were performed using chicken flocks. We then performed molecular typing of Salmonella isolates using conventional polymerase chain reaction (PCR). A new protocol for purification of LPS from Salmonella isolate (S. Typhimurium) was conducted. HPLC analysis of the extracted LPS in the current study was compared to existing methods. An in vivo study was performed to evaluate the ability of LPS to induce an immune response by measuring relative IFN- $\gamma$ and IL-1 $\beta$ gene expression after injecting increasing concentrations of the extracted LPS into SPF chicks.

Results: Isolation and serotyping revealed that Salmonella enterica was of the serovar Typhimurium. Confirmation was conducted by molecular typing through conventional PCR. Fractionation of the LPS extract by HPLC revealed a high degree of purity comparable with standard commercial LPS. These results demonstrate the high purity of extracted LPS based on our modified method using propanol and sodium hydroxide mixture. Intramuscular injection of the extracted LPS in 22 day-old SPF chicks, compared to the negative control, revealed significant upregulation of IFN- $\gamma$ and slight downregulation of IL-1 $\beta$.

Conclusion: The new modified method can be used for high purity LPS extraction and demonstrates effective immunopotentiating activity.

Keywords: extraction, high-performance liquid chromatography, interferon $-\gamma$ and interleukin $1 \beta$ genes expression, LPS (O antigen), purification, quantitative polymerase chain reaction, Salmonella Typhimurium.

\section{Introduction}

Salmonella species are members of the Enterobacteriaceae family. These organisms are Gram-negative motile flagellated bacilli and, except for Salmonella gallinarum and Salmonella pullorum, are non-motile. Salmonella spp. are aerobic or facultative anaerobic and their optimum growth condition is at $37^{\circ} \mathrm{C}[1,2]$. Avian salmonellosis is a serious threat impacting the poultry industry. A massive

Copyright: Hassan, et al. Open Access. This article is distributed under the terms of the Creative Commons Attribution 4.0 International License (http://creativecommons.org/licenses/ by/4.0/), which permits unrestricted use, distribution, and reproduction in any medium, provided you give appropriate credit to the original author(s) and the source, provide a link to the Creative Commons license, and indicate if changes were made. The Creative Commons Public Domain Dedication waiver (http:// creativecommons.org/publicdomain/zero/1.0/) applies to the data made available in this article, unless otherwise stated. increase in the spread of multiple antibiotic-resistant Salmonella has occurred due to the extensive use of antibiotics in human and veterinary medicine [3]. Therefore, bacterial infection control in poultry farms is a crucial step in strategic disease management. Enhancing the natural innate immunity in poultry production is an important method of disease control. Lipopolysaccharide (LPS), which is a basic component of the bacterial cell wall, has been an appropriate tool to increase the innate immunity of susceptible poultry hosts $[4,5]$.

LPS is a major component of Gram-negative bacteria. It is a molecule consisting of lipid A, which is embedded in the outer membrane, a core oligosaccharide, and repeating $\mathrm{O}$-antigen units that extend outward from the surface of the cell [6]. LPS binds to toll-like receptor 4 (TLR4), forming a pattern 
recognition receptor, which initiates a host innate immune response signaling pathway that results in a pro-inflammatory response involving cytokines such as interleukin $1 \beta$ (IL-1 $\beta$ ) and interferon- $\gamma$ $(\mathrm{IFN}-\gamma)[7,8]$.

LPS is a molecule that is important for the virulence and pathogenesis of many bacterial species called endotoxins. Serotyping of Salmonella strains is differentiated based on differences in the LPS O-antigen composition [9-11]. Protocols for LPS extraction, separation, and purification have included the use of various chemical reagents such as butanol [12], ether [13], hot phenol [14], and proteinase $\mathrm{K}$ [15]. The hot phenol method is used to extract a high amount of LPS commercially, based on its effect on denaturing proteins and ability to lyse microorganisms. However, the hot phenol method is limited due to its biohazard nature as the steam hood should be used [16]. In this study, the propanol-sodium hydroxide method was used to extract LPS because of its speed, affordability, and safety since it does not involve use of the public health hazard, phenol. The significance of this study lies in the LPS inoculation of chickens as an effective model of inducing an inflammatory immune response to a bacterial infection without the added complications of live pathogen challenge [4].

LPS administration can activate the immune system leading to the production of high concentrations of IL-6, IL-8, IL-18, and IFN- $\gamma$ in spleen cells $[17,18]$. LPS administration is associated with reduced production of cytokines, such as IL-1 $\beta$, IL-6, and tumor necrosis factor [19].

The aim of this study was to evaluate the purity of the extracted LPS by high-performance liquid chromatography (HPLC) analysis as well as to evaluate the immunopotentiating function of LPS after purification by measuring the relative mRNA expression levels of splenic IL-1 $\beta$ and IFN- $\gamma$ genes.

\section{Materials and Methods}

\section{Ethical approval}

All experimental bird infections were treated in accordance with the regulations for the care and husbandry concerning experimental animals and approved by the Animal Care Committee of Animal Health Research Institute.

\section{Samples}

For Salmonella isolation, liver and spleen samples were aseptically collected from newly deceased or euthanized, diseased chickens of 10 flocks suffering from mortalities and diarrhea.

\section{Isolation and identification of Salmonella}

We performed procedures according to ISO 6579, 2017 [20]. Pre-enrichment of the liver and spleen tissue was done in Buffered Peptone Water $\left(\right.$ Oxoid $\left.^{\circledR}, \mathrm{UK}\right)$. The tissues were then incubated at $37^{\circ} \mathrm{C}$ for $16-18 \mathrm{~h}$ before transferring to Rappaport-Vassiliadis medium
(Conda ${ }^{\circledR}$,Spain). They were then incubated at $41^{\circ} \mathrm{C}$ for $24 \mathrm{~h}$, then streaked onto XLD $\left(\mathrm{LabM}^{\circledR}, \mathrm{UK}\right)$ and SS (Oxoid $\left.{ }^{\circledR}, \mathrm{UK}\right)$ agar plates followed by incubation at $37^{\circ} \mathrm{C}$ for $24 \mathrm{~h}$ aerobically. The typical colonies were identified by biochemical tests (urea agar, triple sugar iron, and lysine iron) (Oxoid $\left.{ }^{\circledR}, \mathrm{UK}\right)$.

\section{Serotyping of isolated Salmonella species}

Isolates were identified in our laboratory by conventional serotyping according to the procedures of ISO 6579, 2014 [21]. We followed the WhiteKauffmann-Le Minor serotyping scheme using Salmonella antiserum (Sifin $\left.{ }^{\circledR}, J a p a n\right)$ [22].

Confirmation of Salmonella Typhimurium using conventional polymerase chain reaction (PCR)

Extraction of bacterial DNA was performed using [23] oligonucleotide primers (Metabion, Germany) as follows: Forward: GGT GGC AAG GGA ATG AA and Reverse: CGC AGC GTA AAG for the target gene $S$. Typhimurium STM4495. The PCR products were separated by electrophoresis on $1 \%$ agarose gel (AppliChem, Germany, $\mathrm{GmbH}$ ) in $1 \mathrm{X}$ TBE buffer at room temperature using gradients of 5 $\mathrm{V} / \mathrm{cm}$. For gel analysis, $20 \mu \mathrm{L}$ of the PCR products were loaded in each gel slot. A 100 bp DNA ladder (Invitrogen, US ) was used to determine the fragment sizes. The gel was photographed by a gel documentation system (Alpha Innotech, Biometra, Germany) and the data were analyzed through computer software.

\section{Extraction and purification of LPS isolated from S. Typhimurium}

The extraction methods used were the phenol method [16] and the alcohol method [24], after corrections [25]. The third approach was based on our modified method [26]. Briefly, $S$. Typhimurium colonies were suspended in peptone water and ultracentrifuged at $10,000 \times g$ for $5 \mathrm{~min}$. The pellets were collected, washed twice with PBS (pH 7.2), and the supernatant was discarded. $S$. Typhimurium pellets derived from the three extraction methods were the same weight $(10 \mathrm{mg})$. The pellets $(10 \mathrm{mg})$ were suspended in $0.5 \mathrm{~mL}$ of a mixture consisting of propanol:sodium hydroxide $(\mathrm{NaOH}) 1 \mathrm{~mol} / \mathrm{mL}(5: 3 \mathrm{v}: \mathrm{v})$ with an alkaline $\mathrm{pH}$ of 11.4 . They were kept in a $20^{\circ} \mathrm{C}$ water bath in a tightly closed Eppendorf tube for $2 \mathrm{~h}$ with gentle mixing by a magnetic stirrer. The mixture was cooled at $-20^{\circ} \mathrm{C}$ and ultracentrifuged at $10,000 \times$ $g$ for $15 \mathrm{~min}$. The supernatant was collected, and the sedimented gel-like layer was extracted using 312.5 $\mu \mathrm{g}$ isopropanol and ultracentrifuged at $10,000 \times g$ for $5 \mathrm{~min}$. The precipitate was discarded and the supernatant was added to the previous supernatant and diluted with an equal volume of distilled water. The sample was centrifuged at $2000 \mathrm{rpm}$ for $5 \mathrm{~min}$. The resulting supernatant was collected and injected on HPLC.

\section{Characterizing LPS isolated from $S$. Typhimurium through HPLC}

The Agilent Series 1200 quaternary gradient pump, Series 1200 autosampler, Series 1200 UV detector, and 
HPLC 2D ChemStation software (Hewlett-Packard, Les Ulis, France) were used in this study. Chromatographic separation was performed on a reversed-phase column (Dionex Acclaim TM 120, C18 [150×4.6 mm, $5 \mu \mathrm{m}]$ ) with a mixture of water and methanol $(65: 35)$ as the mobile phase. Extra pure $S$. Typhimurium LPS (Sigma, Saint Louis, USA) was used as the standard [27].

\section{Standard preparation and chromatographic separation}

A stock standard solution was prepared by dissolving $1 \mathrm{mg}$ of lyophilized LPS in deionized water to prepare the following concentrations $0.005,0.01$, $0.05,0.1,0.5$, and $1 \mu \mathrm{g} / \mathrm{mL}$ within the correlation coefficient $\left(\mathrm{r}^{2}=0.9999\right)$, as shown in Figure-1. The flow rate was $1 \mathrm{~mL} / \mathrm{min}$ with a UV detector at a wavelength of $210 \mathrm{~nm}$. The analyte was injected on HPLC with an injection volume of $10 \mu \mathrm{L}$ and an ambient column temperature. The output of the recovery percent test was used to determine the amount of LPS yielded from the three extraction methods being evaluated. Standard addition is an effective way to evaluate accuracy by adding $10 \mathrm{ng} / \mathrm{g}$ of pure LPS standard to the extracted, known mean concentrations $(45.5,48.42$, and $50.12 \mathrm{ng} / \mathrm{g})$ for the three methods. Standard addition can also be used to assess whether a sample has a matrix effect. If the sample does have a matrix effect, the standard addition procedure provides a more accurate measurement of the concentration of the analyte in the sample than the use of a standard curve [28]. The accuracy of the modified method [26] was assessed by analyzing six replicates of LPS standard calibration curves during a single day. Recovery studies were performed by calculating the recovery and relative standard deviation (RSD\%). The recovery percent acceptance criteria should range between $98 \%$ and $102 \%$ and the RSD $\%$ should be $<1 \%$ [29].

\section{In vivo analysis of LPS administration}

The chickens were divided into five groups (four experimental and one control group) of five chickens each at 22 days old. Different concentrations $(50,100,15$, and $200 \mu \mathrm{g} / \mathrm{mL})$ of LPS

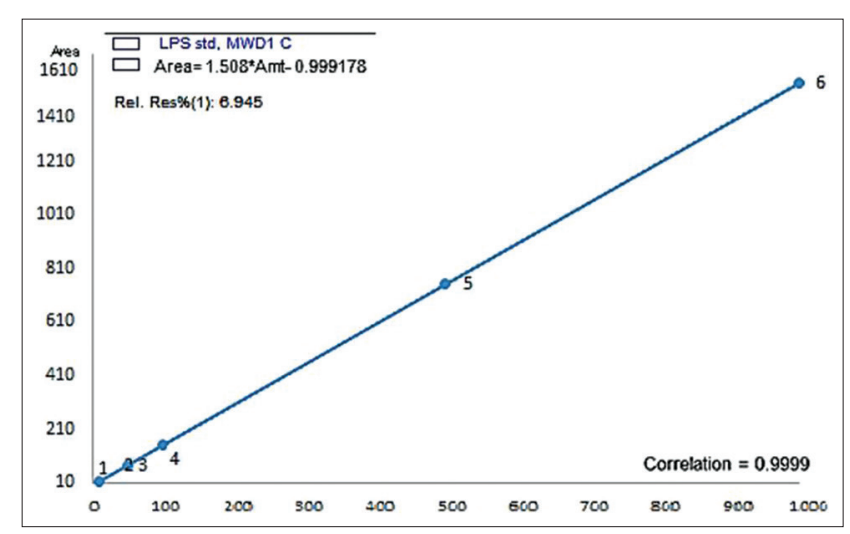

Figure-1: Linearity of lipopolysaccharide standard in deionized water. were inoculated intramuscularly and the control group was injected with saline. Each group was housed in separate controlled biosafety isolators at the Reference Laboratory for Veterinary Quality Control on Poultry Production (RLQP) experiment animal house. Birds were fed antibiotic-free rations and supplied with water ad libitum. A day before LPS injection, samples were collected and tested for Salmonella. After injection, the chicks were kept for $12 \mathrm{~h}$ and then euthanized to prepare for spleen collection. Spleens were stored in RNA later solution.

\section{Quantitative measurement of IL-1 $\beta$ and IFN- $\gamma$ gene expression}

\section{RNA extraction}

RNA was extracted from spleen samples in triplicate using the Biamp RNeasy Mini kit (Qiagen, Germany, $\mathrm{GmbH}$ ) when $30 \mathrm{mg}$ of the spleen tissue sample was added to $600 \mu \mathrm{L}$ lysis buffer (RLT) containing $10 \mu \mathrm{L} \beta$-mercaptoethanol per $\mathrm{mL}$. To homogenize the samples, tubes were placed into the adaptor sets, which were fixed into the clamps of the Qiagen TissueLyser. Disruption was performed for $2 \mathrm{~min}$ at high speed $(30 \mathrm{~Hz})$, with a shaking step. One volume of $70 \%$ ethanol was added to the cleared lysate, and purification of total RNA from animal tissues was performed according to the manufacturer's protocol of the QIAamp RNeasy Mini kit (Qiagen, Germany, $\mathrm{GmbH})$.

\section{Oligonucleotides}

The primers and probes used were supplied from Metabion (Germany) and are shown in Table-1 [30,31].

\section{TaqMan RT-PCR}

PCR amplification was performed in a final volume of $25 \mu \mathrm{L}$ containing $3 \mu \mathrm{L}$ of RNA template, $12.5 \mu \mathrm{L}$ of $2 \times$ QuantiTect Probe RT-PCR Master Mix, $8.1250 .125 \mu \mathrm{L}$ of each probe $(30 \mathrm{pmol})$, and $0.25 \mu \mathrm{L}$ of QuantiTect RT Mix. The reaction was performed in a Stratagene MX3005P real-time PCR machine.

\section{Analysis of qRT-PCR results}

Amplification curves and threshold cycle $(\mathrm{Ct})$ values were determined using the Stratagene MX3005P software. To estimate the quantitative RNA variation of IFN- $\gamma$ and IL- $1 \beta$ gene expression for each sample, the mean $\mathrm{Ct}$ values (of the triplicates) were calculated within each sample for each gene. For the two test genes, expression was normalized to delta $\mathrm{Ct}(\Delta \mathrm{Ct})$ using the geometric mean. Mean $\Delta \mathrm{Ct}$ values were determined for each group compared to the expression of $18 \mathrm{~S}$ rRNA as the endogenous control. Relative expression levels (fold change) were calculated for each comparison between groups using the delta delta $\mathrm{Ct}\left(2^{-\Delta \Delta C t}\right)$ method, as previously published [32]. Fold changes were $\log$ transformed $\left(\log _{2} \mathrm{FC}\right)$ and used to determine pairwise correlations with significance levels of $p \leq 0.05$. 
Table-1: Primers and probes sequences, target genes, and cycling conditions for TaqMan RT-PCR.

\begin{tabular}{|c|c|c|c|c|c|c|}
\hline \multirow{2}{*}{$\begin{array}{l}\text { Target } \\
\text { gene }\end{array}$} & \multirow{2}{*}{$\begin{array}{l}\text { Primers and probes } \\
\text { sequences }\left(5^{\prime}-3^{\prime}\right)\end{array}$} & \multirow{2}{*}{$\begin{array}{c}\text { Reverse } \\
\text { transcription }\end{array}$} & \multirow{2}{*}{$\begin{array}{c}\text { Primary } \\
\text { denaturation }\end{array}$} & \multicolumn{2}{|c|}{ Amplification (40 cycles) } & \multirow[t]{2}{*}{ References } \\
\hline & & & & $\begin{array}{c}\text { Secondary } \\
\text { denaturation }\end{array}$ & $\begin{array}{l}\text { Annealing and } \\
\text { extension }\end{array}$ & \\
\hline 285 & Forward: GGCGAAGC & $50^{\circ} \mathrm{C}$ & $94^{\circ} \mathrm{C}$ & $94^{\circ} \mathrm{C}$ & $60^{\circ} \mathrm{C}$ & {$[30]$} \\
\hline \multirow[t]{5}{*}{ rRNA } & CAGAGGAAACT & $30 \mathrm{~min}$ & $15 \mathrm{~min}$ & $15 \mathrm{~s}$ & $1 \mathrm{~min}$ & \\
\hline & Reverse: GACGACC & & & & & \\
\hline & GATTTGCACGTC & & & & & \\
\hline & Probe: (FAM) AGGACCGCTA & & & & & \\
\hline & CGGACCTCCACCA (TAMRA) & & & & & \\
\hline \multirow{6}{*}{ IFN- $Y$} & Forward: GTGAAGAAGGT & & & & & \\
\hline & GAAAGATATCATGGA & & & & & \\
\hline & Reverse: GCTTTGCGCTG & & & & & \\
\hline & GATTCTCA & & & & & \\
\hline & Probe: (FAM) GGCCAAGC & & & & & \\
\hline & TCCCGATGAACGA (TAMRA) & & & & & \\
\hline \multirow[t]{7}{*}{$I L 1 \beta$} & Forward: GCTCTACATGT & & & & & [31] \\
\hline & CGTGTGTGATGAG & & & & & \\
\hline & Reverse: TGTCGATGTC & & & & & \\
\hline & CCGCATGA & & & & & \\
\hline & Probe:(FAM) & & & & & \\
\hline & CCACACTGCAGCTGGA & & & & & \\
\hline & GGAAGCC (TAMRA) & & & & & \\
\hline
\end{tabular}

IFN- $\gamma=$ Interferon- $\gamma$, IL-1 $\beta=$ Interleukin $1 \beta, R T-P C R=$ Reverse transcription polymerase chain reaction

\section{Results}

Isolation, identification, and serogrouping

Seven Salmonella isolates were detected from the examined samples and all were identified serologically as $S$. Typhimurium 1,4,5,12:1:1,2.

\section{Confirmation of $S$. Typhimurium using conventional} PCR

In the current study, the STM-4495 gene was detected in the isolates of $S$. Typhimurium using corresponding specific primers that produced amplicons with a molecular weight of 915 bp (Figure-2).

\section{Characterization of LPS isolated from $S$. Typhimurium using HPLC}

The best peak resolution was seen at a retention time of $3.479 \mathrm{~min}$. The observed accuracy of the propanol-sodium hydroxide method was $100.16 \pm 0.6$. The purity of the extracted LPS was assessed by HPLC. The extracted LPS from $S$. Typhimurium was analyzed and compared to that of the extra pure commercial standard, as shown in Figure-3. Using the modified propanol-sodium hydroxide method, the HPLC chromatogram of the extracted LPS from $S$. Typhimurium is shown overlaid with that of the LPS standard, indicating the high purity of the product (Figure-4). Furthermore, this chromatogram showed a single major sharp band suggesting very low content of impurities. LPS generated by the alcohol and phenol extraction methods demonstrated differences in the area compared to the LPS standard, which explains the lower recovery percent than the developed propanol-sodium hydroxide method (Figures-5 and 6). This difference may be due the matrix effect of the two other methods. This was determined through standard addition by known concentration (Table-2) [16,24,26].

Our results show that the best method for LPS extraction of the three methods evaluated was our

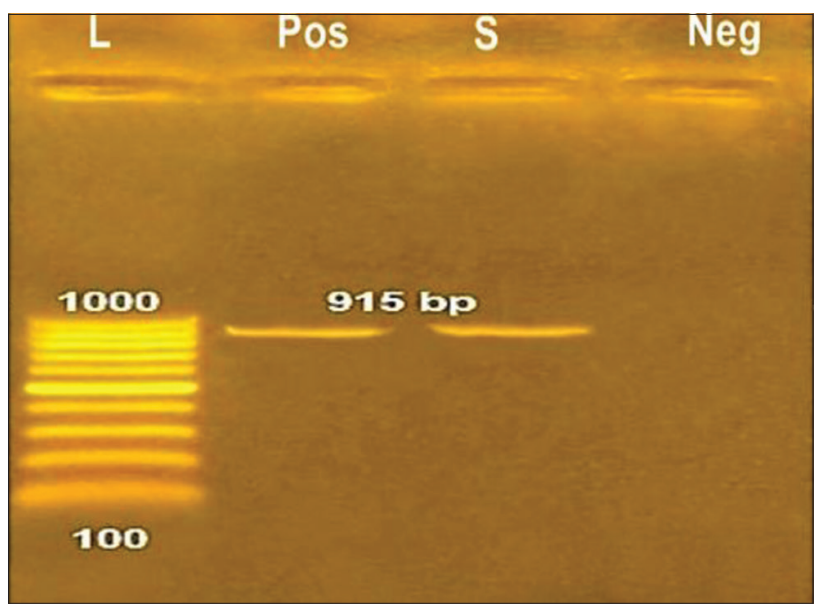

Figure-2: Amplified Salmonella extract lane (S) at the molecular weight as positive control Salmonella reference strain (pos) in 915 bp using conventional polymerase chain reaction.

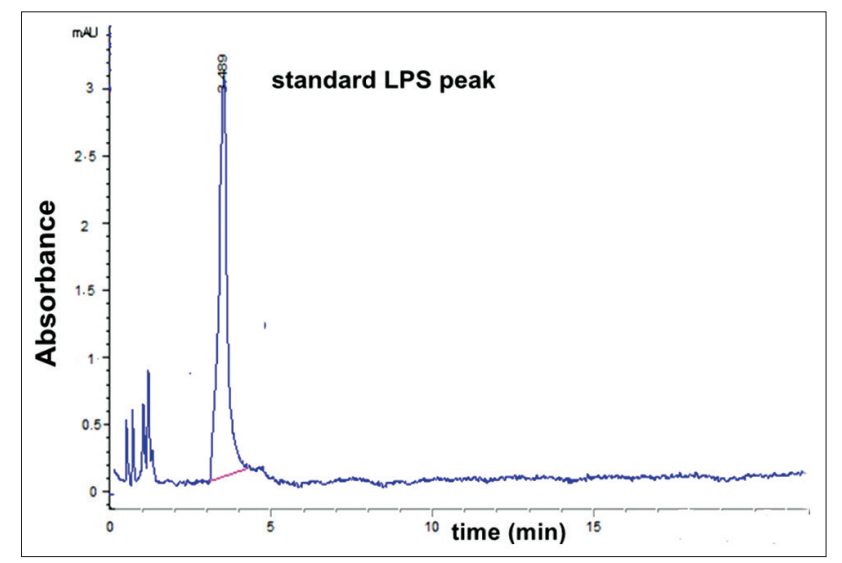

Figure-3: High-performance liquid chromatography chromatogram of standard lipopolysaccharide for Salmonella Typhimurium $(50 \mu \mathrm{g} / \mathrm{kg})$ concentration.

method developed using a mixture of alcohol and sodium hydroxide followed by the alcohol method, 
Table-2: Recovery studies for intraday precision of the three comparable methods and standard addition with known concentration $(10 \mathrm{ng} / \mathrm{g})$.

\begin{tabular}{lcccc}
\hline Methods & $\begin{array}{c}\text { Extracted LPS resulted conc. } \\
\text { (ng/g) } \text { with standard addition }\end{array}$ & $\begin{array}{c}\text { Recovery } \\
\text { \% }\end{array}$ & $\begin{array}{c}\text { Recovery \% } \\
\text { mean } \pm \text { SD }\end{array}$ & $\begin{array}{c}\text { Relative standard } \\
\text { deviation RSD\% }\end{array}$ \\
\hline Phenol method [16] & 54.81108 & 91.35179 & $91.99 \pm 1.137393$ & 1.209106 \\
& 54.52369 & 90.87282 & & \\
& 56.22793 & 93.71321 & & \\
& 54.88754 & 91.47924 & & \\
Alcohol method [24] & 55.51651 & 92.52752 & & \\
& 55.86228 & 93.10379 & & \\
& 58.62296 & 97.70493 & $98.0 \pm 0.574954$ & \\
& 59.02873 & 98.38122 & & \\
& 58.55816 & 97.59694 & & \\
Propanol and $\mathrm{NaOH}$ & 59.29013 & 98.81689 & & \\
method [26] & 58.49397 & 97.48996 & & \\
& 58.96054 & 98.26756 & & \\
& 60.34428 & 100.5738 & $100.2 \pm 0.267508$ & \\
& 59.97293 & 99.95488 & & \\
& 60.27134 & 100.4522 & & \\
\end{tabular}

LPS=Lipopolysaccharide, RSD=Relative standard deviation

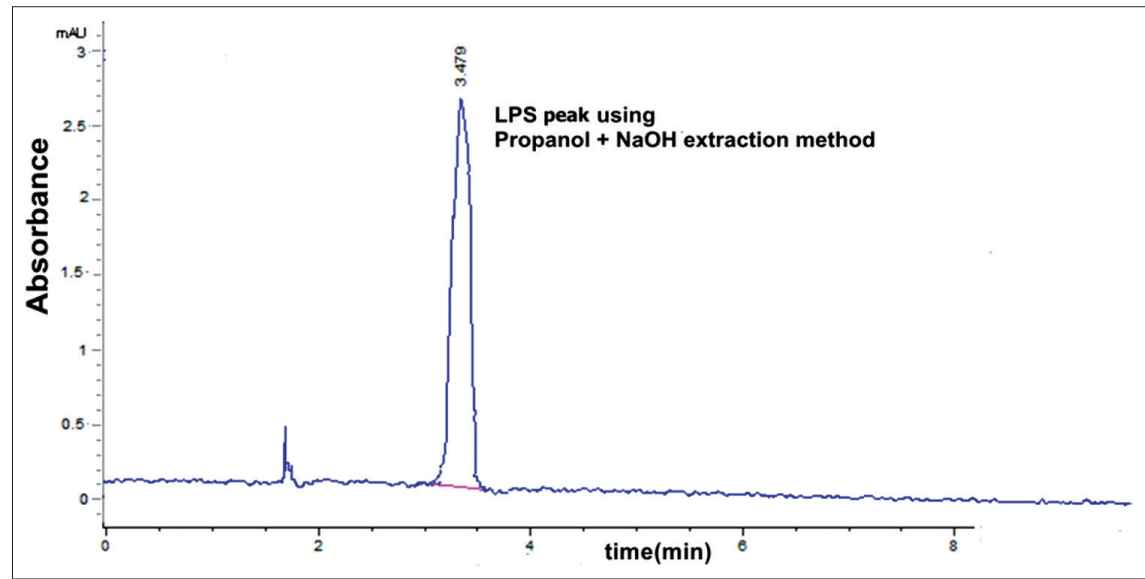

Figure-4: High-performance liquid chromatography chromatogram of extracted Lipopolysaccharide from Salmonella Typhimurium using propanol and $\mathrm{NaOH}$ method $(50 \mu \mathrm{g} / \mathrm{kg})$ concentration.

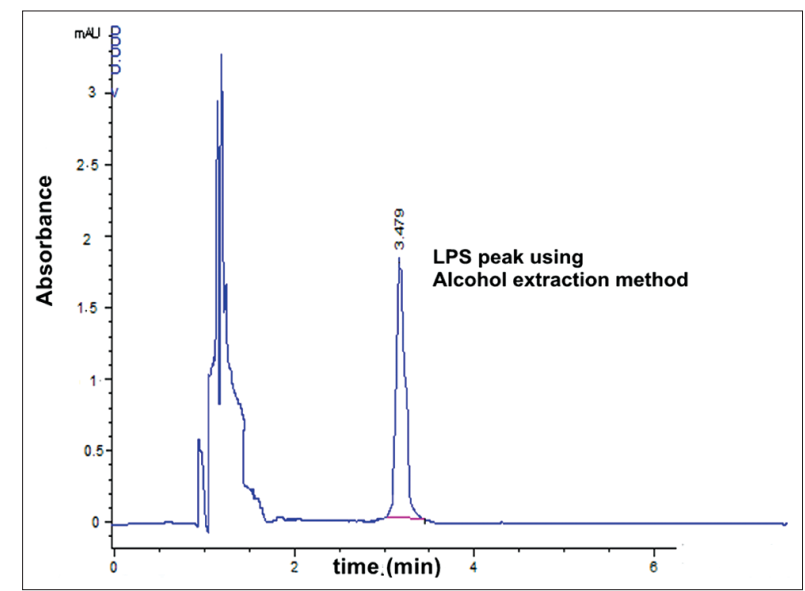

Figure-5: High-performance liquid chromatography chromatogram of extracted Lipopolysaccharide from Salmonella Typhimurium using alcohol extraction method $(50 \mu \mathrm{g} / \mathrm{kg})$ concentration.

with the least effective method being the phenol method. Each gram of bacterial pellets yielded a mean concentration of $6.1 \mu \mathrm{g} / \mathrm{g}$ pure commercial LPS in our developed propanol-sodium hydroxide method. However, the yielded mean concentrations of LPS extracted by the phenol and alcohol methods were 3.001 and $4.85 \mu \mathrm{g} / \mathrm{g}$, respectively, for the same weight of bacterial pellets. The RSD $\%$ was $\leq 1 \%$ to our modified method but Ismail et al. [24], exceeded this RSD\% with the phenol method.

\section{Quantitative measurement of IL-1 $\beta$ and IFN- $\gamma$ gene expression}

Table-3 shows significant upregulation of IFN- $\gamma$ gene expression with increasing LPS concentration. However, IL-1 $\beta$ gene expression showed slight downregulation with increasing concentration of LPS (Figure-7).

\section{Discussion}

Salmonella enterica serovars are important model organisms that induce bacterial pathogenesis and increase innate immunity [8]. As a consequence 


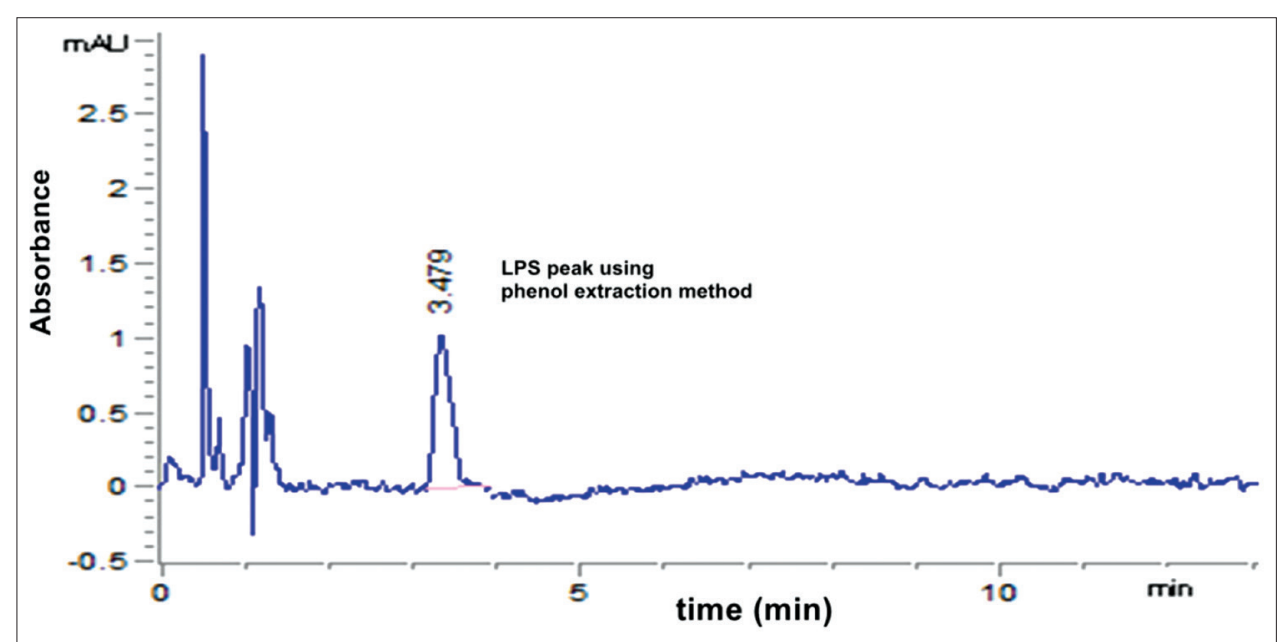

Figure-6: High-performance liquid chromatography chromatogram of extracted Lipopolysaccharide from Salmonella Typhimurium by phenol extraction method $(50 \mu \mathrm{g} / \mathrm{kg})$ concentration.

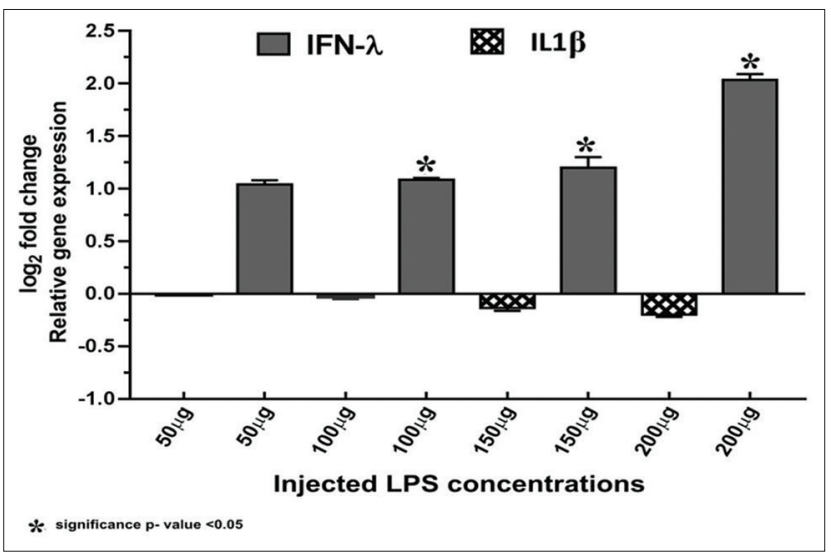

Figure-7: Relative quantification (RQ) gene expression of interferon- $\gamma$ (IFN- $\gamma$ ) and interleukin $1 \beta$ (IL-1 $\beta)\left(\log _{2}\right.$ fold change) showed upregulation of IFN- $\gamma$ expressed gene in correlation with ascending injected concentrations of Lipopolysaccharide $(50,100,150$, and $200 \mu \mathrm{g})$ and downregulation of IL-1 $\beta$ gene. The RQ of each gene, expressed as $\log _{2}$ fold change, was obtained using the $(2-\Delta \Delta \mathrm{Ct})$ method and by normalizing the mRNA expression to $18 \mathrm{~S}$ rRNA ( $* \mathrm{p} \leq$ value).

Table-3: IL-1 $\beta$ and IFN- $\gamma$ splenic gene expression correlated with ascending injecting concentration of LPS. The relative level of each gene, expressed as fold change, was obtained using the $\left(2^{-\Delta \Delta c t}\right)$ method.

\begin{tabular}{lcc}
\hline $\begin{array}{l}\text { LPS conc. } \\
\mathbf{\mu g} / \mathbf{m L}\end{array}$ & $\begin{array}{c}\text { IL-1} \boldsymbol{\beta} \text { fold } \\
\text { change }\end{array}$ & $\begin{array}{c}\text { IFN-y fold } \\
\text { change }\end{array}$ \\
\hline 50 & 0.99 & 1.07 \\
100 & 0.95 & 1.09 \\
150 & 0.84 & 1.30 \\
200 & 0.73 & 2.12 \\
\hline
\end{tabular}

LPS=Lipopolysaccharide, IFN- $\gamma=$ Interferon $-\gamma$, IL- $1 \beta=$ Interleukin $1 \beta$

of host infection with $S$. Typhimurium, its outer membrane structure (LPS) can trigger an immune cytokine storm through the pattern recognition receptor, TLR4 [8]. The previous studies have shown that pure LPS can induce a strong reaction alone or through phagocytic cells from the macrophage-monocyte group, which are sensitive to in vivo injection of LPS and can produce inflammatory molecules such as IFN- $\gamma$ and IL-1 $\beta[33,34]$. A number of methods for extraction, separation, and purification of LPS exist. However, impurities, low yield, or public health concerns are considered as drawbacks for these methods.

In the present study, we evaluated a developed extraction method for LPS and its detection using HPLC and compared the results to traditional LPS extraction methods, the phenol method [16], and the alcohol method [24]. We used a propanol and sodium hydroxide mixture to yield LPS recovery on HPLC that was significantly greater than the other two methods tested (hot phenol and alcohol methods). The retention factor of the modified method (propanol-sodium hydroxide; Figure-4) was equal to the LPS standard (Figure-3) and greater than the other two methods (Figures-5 and 6). As shown in Table-2, the developed propanol-sodium hydroxide extraction method yielded a mean concentration of $6.1 \mu \mathrm{g} / \mathrm{g}$ of bacterial pellets. However, the other two methods yielded 4.85 and $3.01 \mu \mathrm{g} / \mathrm{g}$ mean concentrations of LPS for the same weight of bacterial pellets. Therefore, the current study provides a comparison of three LPS extraction methods proving high yielded mean concentration of LPS compared to a previous study by Rezania et al. [35], which was based only on the phenol method. The main argument against the phenol method was provided by Seite et al. [36] who mentioned that the deproteinizing action of the hot $45 \%$ aqueous phenol on whole cells or isolated and purified endotoxin is caused by the cleavage of a phenol sensitive linkage within the lipid moiety. As a result of this degradation, both the LPS and simple protein fragments retained a part of the lipid moiety. Although not proceeding at the same fast rate as the cleavage of the lipid moiety, this phenol treatment also caused partial hydrolysis of the O-specific side chain and ester-bound fatty acids. This can be explained by the presence of degradation products, which is a main cause of the impurity of the LPS extraction. In this study, we also evaluated LPS extraction through 
the alcohol method [24], in which the precipitate and concentrate LPS fractions were described by Perdomo and Montero [37]. Therefore, sodium hydroxide was chosen as the best chemical to produce LPS with free DNA content $[26,38]$. Here, we show that this modified method using sodium hydroxide produced the best quality and the highest purity LPS compared to the phenol or the alcohol method.

The in vivo experiment was performed to demonstrate the effectiveness of the immunopotentiating impact of the extracted LPS in young SPF chicks. We show elevated splenic RNA expression levels of IFN- $\gamma$ with reduced RNA expression of IL-1 $\beta$. This immune response in chicks was observed at $12 \mathrm{~h}$ post-injection in accordance with the previous studies $[39,40]$. These findings accomplish the aim to produce a new protocol for extraction and purification of LPS with the highest purity and minimum contamination. In addition, we demonstrate that this protocol preserved the biological effectiveness of LPS without any harmful effects or functional impact to the generated LPS extract.

\section{Conclusion}

The protocol presented here can be used to isolate LPS with high purity and functional activity from different strains of smooth Gram-negative bacteria, which have structurally different LPS. The expression of INF- $\gamma$ and IL- $1 \beta$ genes following LPS stimulation clearly indicates its immunostimulating effect in young chicks. Future studies on the potential implications of LPS in improving natural immunity and tolerance to disease infection in the poultry field are, therefore, warranted.

\section{Authors' Contributions}

$\mathrm{HMH}$ and MAF designed the study. MAS designed the in-vivo experiment. HMH performed the bacterial isolation and typing. MAF performed the extraction, purification and HPLC analysis of LPS. MAS performed the molecular typing and the quantitative genes expression. HMH, MAF and MAS analyzed the data, drafted the manuscript, revised and finalized the manuscript for submission. All authors read and approved the final manuscript.

\section{Acknowledgments}

The authors are thankful to the reference laboratory for veterinary quality control on poultry production for providing the infrastructure for conducting the study. The authors did not receive any funds for this study.

\section{Competing Interests} interests.

The authors declare that they have no competing

\section{Publisher's Note}

Veterinary World remains neutral with regard to jurisdictional claims in published institutional affiliation.

\section{References}

1. Gal-Mor, O., Boyle, E.C. and Grassl, G.A. (2014) Same species, different diseases: How and why typhoidal and non-typhoidal Salmonella enterica serovars differ. Front. Microbiol., 5: 391.

2. Saleh, S., Van Puyvelde, S., Staes, A., Timmerman, E., Barbé, B., Jacobs, J., Gevaert, K. and Deborggraeve, S. (2019) Salmonella Typhi, paratyphi A, Enteritidis and Typhimurium core proteomes reveal differentially expressed proteins linked to the cell surface and pathogenicity. PLoS Negl. Trop. Dis., 13(5): e0007416.

3. Cruchaga S., Echeita, A., Aladueña, A., García-Peña, J., Frias, N. and Usera, M.A. (2001) Antimicrobial resistance in salmonellae from humans, food and animals in Spain in 1998. J. Antimicrob. Chemother., 47(3): 315-321.

4. Leshchinsky, T.V. and Klasing, K.C. (2001) Divergence of the inflammatory response in two types of chickens. Dev. Comp. Immunol., 25(7): 629-638.

5. Chen, Y., Zhang, H., Cheng, Y., Li, Y., Wen, C. and Zhou, Y. (2018) Dietary 1-threonine supplementation attenuates lipopolysaccharide-induced inflammatory responses and intestinal barrier damage of broiler chickens at an early age. Br. J. Nutr., 119(11): 1254-1262.

6. Bohl, T.E. and Aihara, H. (2018) Current progress in the structural and biochemical characterization of proteins involved in the assembly of lipopolysaccharide. Int. J. Microbiol., 2018: 5319146.

7. Kogut, M.H., He, H. and Kaiser, P. (2005) Lipopolysaccaride binding protein/CD14/TLR-4 dependent recognition of Salmonella LPS induces the functional activation of chicken heterophils and up-regulation of pro-inflammatory cytokine and chemokine gene expression in these cells. Anim. Biotechnol. 16(2): 165-181.

8. Keestra-Gounder, A.M., Tsolis, R.M. and Bäumler, A.J. (2015) Now you see me, now you don't: The interaction of Salmonella with innate immune receptors. Nat. Rev. Microbiol., 13(4): 206-216.

9. Pier, G.B. (2007) Pseudomonas aeruginosa lipopolysaccharide: A major virulence factor, initiator of inflammation and target for effective immunity. Int. J. Med. Microbiol., 297(5): 277-295.

10. Pastelin-Palacios, R., Gil-Cruz, C., Pérez-Shibayama, C.I., Moreno-Eutimio, M.A., Cervantes-Barragán, L., Arriaga-Pizano, L., Ludewig, B., Cunningham, A.F., García-Zepeda, E.A., Becker, I., Alpuche-Aranda, C., Bonifaz, L., Gunn, J.S., Isibasi, A. and López-Macías, C. (2011) Subversion of innate and adaptive immune activation induced by structurally modified lipopolysaccharide from Salmonella Typhimurium. Immunology, 133(4): 469-481.

11. Laughlin, R.C., Mickum, M., Rowin, K., Adams, L.G. and Alaniz, R.C. (2015) Altered host immune responses to membrane vesicles from Salmonella and gram-negative pathogens. Vaccine, 33(38): 5012-5019.

12. Szermer-Olearnik, B. and Boratyński, J. (2015) Removal of endotoxins from bacteriophage preparations by extraction with organic solvents. PLoS One, 10(3): e0122672.

13. Grivaud-Le Du, A., Zykwinska, A., Sinquin, C., Ratiskol, J., Weiss, P., Vinatier, C. and Colliec-Jouault, S. (2017) Purification of the exopolysaccharide produced by Alteromonas infernus: Identification of endotoxins and effective process to remove them. Appl. Microbiol. Biotechnol., 101(17): 6597-6606.

14. Kulikov, E.E., Golomidova, A.K., Prokhorov, N.S., Ivanov, P.A. and Letarov, A.V. (2019) High-throughput LPS profiling as a tool for revealing of bacteriophage infection strategies. Sci. Rep., 9(1): 2958.

15. Chowdhury, F.A., Nurul, I.M., Saha, A., Mahboob, S., Mosaddek, A.S.M., Omar, F.M. and Bhattacharjee, R. (2015) Purification, extraction and visualization of lipopolysaccharide of Escherichia coli from urine samples of patients with urinary tract infection. Avicenna J. Clin. 
Microbiol. Infect., 2(4): e31990.

16. Davis, M.R. Jr. and Goldberg, J.B. (2012) Purification and visualization of lipopolysaccharide from gram-negative Bacteria by hot aqueous-phenol extraction. J. Vis. Exp., (63): 3916.

17. Milner, J.D., Zhu, J. and Paul, M. (2019) Continued fascination-a tribute to a giant in immunology, Dr. William E. Paul. Front. Immunol., 10: 354.

18. Li, W., Yang, S., Kim, S.O., Reid, G., Challis, J.R. and Bocking, A.D. (2014) Lipopolysaccharide-induced profiles of cytokine, chemokine, and growth factors produced by human decidual cells are altered by Lactobacillus rhamnosus GR-1 supernatant. Reprod. Sci., 21(7): 939-947.

19. Kany, S., Vollrath, J.T. and Relja, B. (2019) Cytokines in inflammatory disease. Int. J. Mol. Sci., 20(23): 6008.

20. International Organization for Standardization. ISO 6579. (2017) Microbiology of the Food Chain-horizontal Method for the Detection, Enumeration and Serotyping of Salmonella-Part 1: Detection of Salmonella spp. International Standards Organization, Geneva.

21. International Organization for Standardization. ISO 6579. (2014) Microbiology of Food and Animal Feeding Stuffshorizontal Method for the Detection of Salmonella. Part 3. International Standards Organization, Geneva.

22. Grimont, P.A.D. and Weill, F.X., (2007) Antigenic formulas of the Salmonella serovars. WHO Collaborating Centre for Reference and Research on Salmonella. $9^{\text {th }}$ ed. Institut Pasteur, Paris.

23. Liu, B., Zhou, X., Zhang, L., Liu, W., Dan, X., Shi, C. and Shi, X. (2012) Development of a novel multiplex PCR assay for the identification of Salmonella enterica Typhimurium and Enteritidis. Food Control, 27(1): 8-93.

24. Ismail, M.T., El-Enbaawy, M., Rawy, E., Mohamed, E. and Fadel, M.A. (2018) Comparative study on one shot lipid a and montanide (TM) ISA 70 adjuvanted Pasteurella vaccines for rabbits. Biosci. Res., 15(3): 2374-2382.

25. El Hamidi, A., Tirsoaga, A., Novikov, A., Hussein, A. and Caroff, M. (2005) Microextraction of bacterial lipid a: Easy and rapid method for mass spectrometric characterization. J. Lipid Res., 46(8): 1773-1778.

26. Fadel, M.A. and Hassan, H.M. (2019) Validated method for extraction and purification of lipopolysaccharide from Escherichia coli and Salmonella by HPLC. Anim. Health Res. J., 7(3): 1-10.

27. Pais de Barros, J.P., Gautier, T., Sali, W., Adrie, C., Choubley, H., Charron, E., Lalande, C., Le Guern, N., Deckert, V., Monchi, M., Quenot, J.P. and Lagrost, L. (2015) Quantitative lipopolysaccharide analysis using HPLC/MS/ MS and its combination with the limulus amebocyte lysate assay. J. Lipid Res., 56(7): 1363-1369.

28. Jaffar, B.M., Swart, H.C., Ahmed, H.S., Yousif, A. and Kroon, R.E. (2019) Luminescence properties of Bi doped
La2O3 powder phosphor. J. Lumin., 209: 217-224.

29. Food and Drug Administration, HHS. (2013) International conference on harmonisation; guidance on Q4B evaluation and recommendation of pharmacopoeial texts for use in the international conference on harmonisation regions; annex 14 on bacterial endotoxins test general chapter; availability. Notice. Fed. Regist., 78(205): 63221-63222.

30. Mar, J.C., Kimura, Y., Schroder, K., Irvine, K.M., Hayashizaki, Y., Suzuki, H., Hume, D. and Quackenbush, J. (2009) Data-driven normalization strategies for high-throughput quantitative RT-PCR. BMC Bioinformatics, 10: 110 .

31. Samy, A., Mady, W., Hagag, N.M., Mohamed, S., AlShamy, E. and Hassan, M.K. (2016) Immune-related gene expression in response to different strains of Egyptian low pathogenic H9N2 infection in chicken peripheral blood mononuclear cells. Br. J. Virol., 3: 166-176.

32. Yuan, J.S., Reed, A., Chen, F. and Stewart, C.N. Jr. (2006) Statistical analysis of real-time PCR data. BMC Bioinformatics, 7: 85 .

33. Russell, L., Dedrick, G., Paul, J. and Conlon, B. (1995) Prolonged expression of lipopolysaccharide (LPS)-induced inflammatory genes in $\mathrm{W}$ hole blood requires continual exposure to LPS. Infect. Immun., 63(4): 1362-1368.

34. Yasuda, K., Nakanishi, K. and Tsutsui, H. (2019) Interleukin-18 in health and disease. Int. J. Mol. Sci., 20(3): 649 .

35. Rezania, S., Amirmozaffari, N., Tabarraei, B., JeddiTehrani, M., Zarei, O., Alizadeh, R., Masjedian, F. and Zarnani, A.H. (2011) Extraction, purification and characterization of lipopolysaccharide from Escherichia coli and Salmonella Typhi. Avicenna J. Med. Biotechnol., 3(1): 3-9.

36. Seite, S., Breton, A., Novikov, A., Martin, R., Tissières, P. and Caroff, M. (2017) All Bacteria lipopolysaccharides are not endotoxins: Structure to activity relationships: Vitreoscilla filiformis example: 4447. J. Am. Acad. Dermatol., 76(6): AB36.

37. Perdomo, R. and Montero, V. (2006) Purification of E. coli 055: B5 lipopolysaccharides by size exclusion chromatography. Biotechnol. Apl., 23(2): 124-129.

38. Park, H.J., Oh, S., Vinod, N., Ji, S., Noh, H.B., Koo, J.M., Lee, S.H., Kim, S.C., Lee, K.S., Choi, C.W. (2016), Characterization of chemically-induced bacterial ghosts (BGs) using sodium hydroxide-induced vibrio parahaemolyticus ghosts (VPGs). Int. J. Mol. Sci., 17(11): 1904.

39. Leshchinsky, T.V. and Klasing, K.C. (2003) Profile of chicken cytokines induced by lipopolysaccharide is modulated by dietary alpha-tocopheryl acetate. Poult. Sci., 82(8): 1266-1273.

40. Kaiser, M.G., Block, S.S., Ciraci, C., Fang, W., Sifri, M. and Lamont, S.J. (2012) Effects of dietary Vitamin E type and level on lipopolysaccharide-induced cytokine mRNA expression in broiler chicks. Poult. Sci., 91(8): 1893-1898. 